\title{
MOVIMENTOS DO CORPO EM DANÇA: DO CORPO-SEM-ÓRGÃOS AO CORPORAR
}

\author{
Jardel Sander Silva ${ }^{1}$ - Doutor (PUCSP) \\ jardelss@gmail.com
}

Vivemos numa cultura contemporânea arrebatada pela produção de imagens prêt-à-porter. A imagética da vida, nosso cotidiano, abarca todos os aspectos do nosso modo de vida, mas recai com especial predileção sobre o corpo. Sim, o corpo humano, visto, revisto e revirado por uma excessiva produção de imagens, que o escrutina nas mais recônditas dobras de sua existência.

Mas também as artes, amiúde, instalam-se confortável e acriticamente nesta imagética contemporânea. Especialmente as artes do corpo, que em grande parte de sua produção tem nos oferecido palatáveis espetáculos de virtuosismo, cuja forma se sobrepõe à força com lastimável frequência.

Nosso principal problema, para não cairmos em qualquer saudosismo por um passado idílico, é que a imagética espetacular de nossos tempos tende a produzir evidências, tende a evidenciar. E nossa evidenciante atualidade, absolutamente mergulhada no afã pelo movimento e pela velocidade, parece ter conferido ao corpo o destino de habitar esse território de inexorável "transformação". Não propriamente de devir; mas dessa noção, por assim dizer, pós-moderna de rápida mudança, de frenesi transformista. $\mathrm{E}$ parece que as artes do corpo, embora busquem questionar esse império das imagens-evidências, amiúde fracassam quando é necessário sair da experimentação para a expressão (ou mesmo apresentação). Seria porque o experimentado é inapresentável? Seria porque as artes também não conseguiram conferir consistência às suas produções quando não espetaculares? Ou talvez porque não tenhamos tematizado suficientemente a questão que envolve o corpo nas artes - na dança, especificamente - em suas relações com o movimento e com a expressão?

Neste texto, procura-se refletir acerca dessas questões. Sobretudo, busca-se tecer uma crítica à hipostasia por que o corpo, contemporaneamente, tem passado, reduzindo-o a uma imagética, e transformando-o num corpo-imagem. A tentativa deste artigo é dar consistência a um corpo-movimento, através da dança, sublinhando um conceito desenvolvido para dar conta da especificidade do corpo-em-dança, qual seja, corporar.

\footnotetext{
1 Dançarino, performer, professor do curso de Dança da Escola de Belas Artes (EBA) - UFMG, na área de performance e dança e novas tecnologias; pós-doutorado na UFSC (bolsista CNPq); doutorado na PUCSP (sob orientação de Suely Rolnik); integrante do grupo Zona de Interferência (Belo Horizonte/MG) e do coletivo de dança planoB (Florianópolis).
} 


\section{CORPO E MOVIMENTO}

Mesmo que com muita frequência tem-se problematizado e tecido críticas ao imperativo de um corpo tornado imagem em nossa contemporaneidade, também a relação que se tem estabelecido entre corpo e movimento apresenta-se numa faceta paradoxal, uma vez que o movimento em questão - até mesmo como um derivativo da imagem - tem se caracterizado mais por uma intensa velocidade estacionária. Ou, falando corriqueiramente, mexer-se muito para não sair do lugar.

O paradoxo que se nos apresenta é o de subsistir, em meio ao império da velocidade e do efêmero (nossa assim chamada "pós-modernidade"), uma estranha conservação: uma engenhosa forma de manutenção e sustentação do estado de coisas através do movimento, no interior mesmo de nossa extrema fluidez atual.

A nossa contemporaneidade nos apresenta uma pluralidade de culturas díspares e (supostamente) interligadas. Como se a supressão espaço-temporal (via globalização) nos situasse numa grande comunidade global, tão rica quanto "conectada".

Nesse cenário, o corpo parece servir de anteparo para múltiplas projeções da utópica aldeia global: em sua inelutável evidência, apresenta-se como signo comum da existência humana em qualquer lugar; e, de modo similar, demonstra sua inquestionável capacidade de "transformar-se".

O resultado lógico da constatação de uma pluralidade cultural em toda sua fluidez e intercambialidade, e de corpos transformáveis não poderia senão nos conduzir à - também evidente - constatação de que as subjetividades estão, por seu turno, em processos de mudança, transformando-se.

A imagem geral que emerge dessas "constatações" todas, como é próprio a um otimismo evolucionista, é que estamos seguindo o natural, embora contraditório, curso da evolução. Estamos melhorando, temos melhorado.

No entanto, e esse é o paradoxo de que falávamos acima, há estranhos movimentos de conservação que estagnam, amiúde, corpos e subjetividades. 0 que seriam exatamente estes movimentos? Simples e temerários anacronismos? Tentativas de sobrevivência? Sintomas de que a transformação talvez passe por outras vias que não a da obviedade evolutiva? Formas, às vezes marcadamente obsoletas e mal-sucedidas, de resistência? Ao que nos interessa aqui, podemos pensar que há algo de conservador na extrema evidência que o corpo tem assumido e na insistência com que somos convocados a nos familiarizarmos com ele.

Poderíamos mesmo dizer que o corpo nos ocupa. Isto é, frente ao risco do "sujeito" se esvaziar, ele foi preenchido. 0 corpo recheia o humano. As subjetividades são referidas cada vez mais ao corpo, 
mas não para aproveitarem-se de seu devir, de sua processualidade; e sim na tentativa desesperada de sustentarem um si-mesmo mais exterior, mais imagético.

De fato, o corpo nos ocupa. Mas não só: nos invade, está presente a todo momento. Suas imagens, suas transformações, sua saúde, sua beleza, seu prazer. É quase opressiva a presença do corpo no nosso dia-a-dia, principalmente através da mídia. 0 que poderia levar-nos a perguntar: o que se pode ainda falar sobre o corpo? Talvez seja necessário não mais se falar em corpo, não mais querer defini-lo por aquilo que ele mostra, ou por aquilo que nele se mostra. Mas também, não buscar o que ele ocultaria, tesouro guardado, pronto a cintilar nas mãos do descobridor.

Quem sabe possamos buscar outra expressão para as experiências que rejeitam o corpo. Pois, afinal, não teria se tornado impossível, atualmente, falar do corpo sem querer evidenciá-lo? Quer dizer, sempre que se fala dele, está-se fadado a reposicioná-lo, aproximando-o da forma-homem, fazendo 0 corpo servir de suporte ao humano.

Se pensarmos nos processos de subjetivação contemporâneos, e nesta tentativa de sairmos da obviedade, será necessário que arranquemos da carne qualquer coisa de inaudível, de impronunciável. Consideremos a possibilidade de partir do óbvio, e daí derivar: será que não se poderia pensar o corpo como potência do inumano, uma possibilidade de transposição do humano, ou, usando um termo caro a Nietzsche, experimentações do além-homem? Como se, na sua quase insuportável contradição, essa possibilidade descortinasse uma linha de fuga atroz, cruel, pulsante: na obviedade plácida de que todo corpo é o espaço por excelência do humano, justamente aí decompô-lo, fazendo o corpo buscar o intensivo que escapa aos órgãos (corpo-sem-órgãos), envolvendo os presentes num ritual de espanto, de estranheza, em que o corpo (em sua organização) vai se tornando inumano em sua recomposição intensiva: devir corpo.

O que nos aguarda para além do corpo? Há ainda carne, ossos e pele? Para qual nova fronteira estamos sendo arrastados? O corpo nos convida a ultrapassá-lo enquanto morada do humano. Arrastanos ao que Deleuze e Guattari denominam - inspirados por Antonin Artaud - de corpo-sem-órgãos. E mais que isso: o corpo nos convida a processualidades abertas, ao que queremos sustentar neste artigo como um corporar.

\section{DEVIR NÃO É DESENCARNAR}

Nessa nova empreitada, algumas prudências são importantes. Primeiramente, não cair na tentação de desencarnar para liberar os fluxos, na utópica tentativa, por exemplo, de erigir um corpo informático, de pura informação, como esboçado na crítica que Le Breton (2003, p.123-137) faz à negação do corpo presente em alguns entusiastas da cibercultura. Para estes - incluindo-se aí o papa do LSD dos 
anos 60, Timothy Leary - o pós-humano passa pela elisão do corpo, como forma de escapar de sua gravidade e, conseqüentemente, da imprevisibilidade dos encontros, o que conduziria esse novo sujeito a encarnar "um cogito puro", numa espécie de novo gnosticismo. Nas palavras conclusivas de Le Breton:

O discurso do fim do corpo é um discurso religioso que crê no advento do Reino dos Céus. No mundo gnóstico do ódio ao corpo que é antecipado por parte da cultura virtual, o paraíso é necessariamente um mundo sem corpo, equipado de chips eletrônicos e de modificações morfológicas. (Le Breton, 2003, p. 136)

De fato, temos vivido enredados numa política de subjetividade que espreme nossas experimentações num corpo previamente formatado. Daí que tenhamos buscado, amiúde, uma saída na fluidez da informação, ou melhor, da informática:

\begin{abstract}
O corpo é visto por alguns entusiastas das novas tecnologias como um vestígio indigno fadado a desaparecer em breve. Ele se transforma em membro excedente, em obstáculo à emergência de uma humanidade (que alguns já chamam de pós-humanidade) finalmente liberta de todas as suas peias, das quais a mais duradoura é o fardo do corpo. (Le Breton, 2003, p. 123)
\end{abstract}

Mas o que se nega aí é justamente a problemática do corpo como dispositivo de atualização. Pois o que está em questão para este corpo espremido é similar ao que ocorre ao corpo epiléptico: uma onda, uma intensidade que atravessa uma carne formatada, desfigurando-a. Nossa experiência do corpo comum ou trivial ${ }^{2}$ aponta, contemporaneamente, a uma incapacidade para encarnar certas qualidades de forças que 0 atravessam, como se aquilo que convencionamos chamar corpo estivesse tão achatado e reduzido que não suportaria mais certas intensidades, não suportaria a desfiguração. Pois há, certamente, uma desfiguração própria ao corpo, e que Deleuze reportará à sensação: "a sensação é a mão da deformação, o agente da deformação dos corpos" (Deleuze, 1981, p. 28). Ele se refere às pinturas de Francis Bacon. Mas porque não podemos pensar também nas experimentações dos corpos e em sua desfiguração? Se um corpo é afetado pelas forças do mundo - o corpo vibrátili3, segundo Rolnik (2006) - não o seria justamente pela ativação de suas sensações?

Nesse processo o corpo é lançado no paradoxo: um corpo paradoxal, segundo José Gil (2002). E o assombro é inevitável, o que explicaria o porquê desta tentativa de elidir do corpo sua carne, sublinhando uma desencarnada fluidez, como forma de eliminar o paradoxo que lhe é inerente.

No entanto, não será negando o corpo, ou reduzindo-o a um processador de informações que se abrirá o caminho para os fluxos, para a vida. Pois quando se desencarna o corpo, escamoteia-se seu paradoxo, abranda-se sua desfiguração, e, nesse processo, esvaziam-se também suas intensidades. Por isso, se quisermos traçar linhas de fuga a partir do corpo, é preciso arrancá-lo de sua estratificação, mas

2 Para as noções de corpo comum (ou empírico comum) e corpo trivial, cf. Gil, 2002: 131 e ss.

3 O conceito de corpo vibrátil foi elaborado por Suely Rolnik (2004; 2006), e nos remete a um modo de subjetivação que configura o mundo à maneira como este se apresenta ao corpo, na forma de vibração e contágio. Esse modo implica, sobretudo, uma vulnerabilidade ao mundo.

22

Revista "O Teatro Transcende" do Departamento de Artes - CCE da FURB - ISSN 2236-6644 - Blumenau, Vol. 17, № 1, p. 19 - 38, 2012 
sem volatilizá-lo em informação.

É preciso, pois, conduzi-lo a novos limiares, aproximando-o de uma zona de intensidades livres, "reino do devir, uma tempestade de forças, o não-estratificado, o informe, um 'espaço anterior', espaço de singularidades, no qual as coisas não são ainda" (Levy, 2003, p. 78). É assim que Tatiana Salem Levy (2003), em sua leitura da aproximação que Deleuze realiza em relação à obra de Foucault, apresenta-nos o Fora (dehors) (ibid.). E este Fora não é necessariamente um lugar, ou um espaço-tempo; é ele justamente aquilo que nos arranca dos lugares: desterritorialização. Talvez a experimentação do corpo nas franjas deste Fora nos abra para um além-corpo, ou melhor, talvez 0 além-corpo passe por uma abertura porosa do corpo ao Fora e pela invenção de estratégias de não-enlouquecimento e não-morte. E a tentativa deste exercício não pode cair na reatividade que se manifesta na negação do corpo; o além-corpo é um desdobramento em relação à sua estratificação atual. O procedimento implica o inabitual, uma busca pelo não familiar no corpo, numa espécie de ampliação. Mas também uma desfiguração.

Uma desfiguração do corpo - seguindo a linha de Deleuze-Bacon - é operada pela sensação, que expõe o corpo ao contato com as forças do mundo, com a presença viva do outro. E se o corpo se desfigura, é para tentar encarnar essas forças que o tomam. A desfiguração não quer dizer que o corpo deixe de ser corpo; ele deixa de ser carne formatada, abrindo-se à encarnação, ao intensivo.

Este procedimento, enquanto experimentação, demanda uma outra qualidade de movimento, talvez mesmo uma outra velocidade. Poderíamos supor que a lentificação, ou desaceleração reintroduzisse 0 corpo no intensivo. Mas não há solução fácil entre aceleração e lentidão. Pois se encontra no aumento de velocidade (ou seja, na aceleração) uma prontidão para o movimento. Ou melhor, ao se acelerar o corpo, abre-se pequenas brechas para fazer passar fios de invenção. Como se o corpo pudesse se reinventar através da provisoriedade do movimento, mais do que por sua excelência performática, ou estagnação fotogênica. Pois é disso que se trata: a aceleração vai aproximando o corpo dos seus limiares a partir do caráter provisório experimentado no movimento, e apresenta possibilidades de se romper com alguns automatismos corporais.

Nesse aspecto, há um exercício de contato improvisação 4 que se faz a partir do rolamento do corpo no solo, buscando manter o maior contato corporal possível com o chão. À medida que se vai acelerando o movimento, ou seja, aumentando a velocidade do rolamento, amplia-se a prontidão para a ação. Isto é, o corpo reage à ação $0^{5}$, não às ideias ou pré-disposições mentais. Improviso. E, nesse aspecto, po-

4 Contato-improvisação é uma técnica de dança contemporânea em que os movimentos, a dança, originam-se de pontos de contato: improvisa-se a partir do contato. Funciona segunda uma lógica física de ação-reação, através de movimentos que exploram transferência de peso, rolamentos, quedas, suspensões etc. $O$ contato-improvisação surge no começo dos anos 1970, nos EUA, a partir das experimentações de um grupo de dançarinos, liderados por Steve Paxton e Nancy Stark Smith.

5 Nietzsche, para distinguir os tipos senhor e escravo, em sua Genealogia da Moral, faz uma distinção em termos das forças que prevalecem em cada um. $O$ que interessa a Nietzsche é a afirmação da vida, o que se dá pela prevalência da ação nas condutas, o que distingue, primeiramente, a reação (re-agir) do ressentimento (re-sentir); mas também, mais profundamente, o tipo senhor do tipo escravo. Por isso, para este autor, a verdadeira reação é a da ação (Nietzsche, 1998: 28 (I, §10)). Essa discussão sobre ação e reação é retomada mais à frente, em termos de movimento corporal. 
de-se dizer que na aceleração do movimento se encontra uma outra possibilidade de relação entre pensamento e corpo. Mas, por outro lado, na lentificação também, na medida em que nos faz mais presentes, tornando o movimento presente ao corpo e ao pensamento, aguçando a sensibilidade ao que se passa com o corpo, com o espaço e com o tempo.

Podemos pensar que lentificação e aceleração operem juntas na potencialização do corpo, na medida em que representam diferenças na sua atualização através do movimento. Não qualquer movimento, é claro; trata-se aqui do movimento dançado, mais especificamente, do contato improvisação, ou ainda do corpo em estado de improvisação. E é a partir deste movimento que se pode falar de outra qualidade da relação pensamento-corpo: um corpo pensante, ou um pensamento em corpo.

Ou, então, aproximando-nos um pouco de Henri Bergson ${ }^{6}$, um pensamento movente, e não mais um pensamento sobre o movimento, que muitas vezes quer conduzi-lo. Pois a relação que se busca entre pensamento e movimento corporal, no intuito de criar, é da ordem da parceria, não da prevalência.

\section{VELOCIDADE VERSUS PRESSA}

O problema, pois, não está na própria velocidade; mas na forma de encarná-la, e numa falta de consistência que faz do corpo-subjetividade tomado por uma ininterrupta velocidade - a pressa - 0 anteparo para uma infinidade de clichês do consumo, no seu afã de habitar o interior mesmo da velocidade, de não "estar de fora". Por isso, cabe uma ressalva: é preciso diferenciar velocidade de pressa, pois esta última parece jogar os corpos (e as vidas) numa fragilidade, ou mesmo numa despotencialização, fazendoos retornar a si, num alheamento e indiferença - o que é o contrário da expansão; é um ostracismo. A aceleração serve a certos modos dos fluxos da força vital: frente a uma pulsação que pede passagem, ela oferece um ritmo, uma sintonia. Já a pressa, é a pura aceleração, sem passagens: é o oco da velocidade, uma volúpia teleológica, que obedece a um fim previamente determinado, qual seja, não parar!

Denise de Sant'Anna7 nos fala dos corpos e suas velocidades, de nossa contemporaneidade apressada, e de como no início do século XX várias "inovações", entre elas o automóvel, contribuíram para nos lançar no afã da velocidade. E se, por um lado, isso pode ter representado novas liberdades - "a possibilidade de liberação do homem de sua geografia e de sua história” (Sant'Anna, 2001, p. 14) -, por outro, trouxe uma forma renovada da agonia. Além disso, jogou-nos numa extrema fluidez: "Fluidez dos corpos e desmanche de seus limites" (ibid.: 15). O que não deixa de ser interessante, em termos de processualidade, não fosse o fato dessa fluidez e da extrema velocidade terem engendrado um instantaneísmo, que, a exemplo do que ocorre com a percepção do corpo dentro de um avião a jato, em que "o movimento trans-

6 Cf. Bergson, 1974: 105 e ss.

7 Cf. Sant'Anna, 2001, principalmente pp. 13-28 e pp. 41-54. 
forma-se em repouso" (ibid.: 16), assenta-nos num movimento estacionário, tal qual aquelas moscas cuja extrema velocidade de suas asas dão a impressão de permanecerem estáticas no ar. Ou seja, aceleramonos, mexemo-nos demais para não sairmos do lugar, para permanecermos exatamente onde estávamos.

Daí que se pense em desaceleração como contraponto lógico à problemática da velocidade, como uma forma de "limpar" o corpo. Mesmo não havendo grau zero do corpo, como nos adverte Sant'Anna, sente-se a necessidade de introduzir o corpo num outro regime de experimentação, que não reduza seu movimento a um instantâneo fotogênico. Mas, nesse aspecto, a ideia de desaceleração se mostra restrita, pois, como já foi dito, há sim uma prontidão para a ação que se encontra nos movimentos acelerados. 0 problema está, pois, na extrema fluidez e na repetição do mesmo a que ela conduz.

Por isso, a questão deve ser deslocada de um problema referente à velocidade, para outro, referente à densidade: na extrema fluidez exigida - e oferecida - aos corpos, falta-lhes consistência. Adensar, então, seria um caminho: como se o corpo, numa determinada experimentação, fosse imerso nalguma substância mais densa, que retardasse os movimentos, intensificando-os através da desaceleração. Ou mesmo, como se o próprio corpo se adensasse, instaurando uma outra qualidade de relação com o movimento. Porque, afinal, o que se adensa é a sensação neste corpo.

Este procedimento, que marca a consistência das sensações no corpo, é o adensamento. Ele visa, por um lado, fazer frente à extrema fluidez dos processos de subjetivação contemporâneos; e, por outro, dar uma alternativa não cristalizadora aos processos, como uma forma de territorialização porosa. Além disso, o adensamento refere-se especialmente ao movimento corporal. E nesse sentido, ele serve de modo às processualidades próprias ao corpo, ao seu devir, e de abertura a uma relação entre pensamento e corpo, que estabelece uma zona de trânsito.

\section{CORPORAR}

É na experimentação em contato improvisação que esta ideia ganha sentido, viabilizando outra forma de se experimentar movimento e pensamento, diferentemente daquela das práticas do corpo habitual e cotidiano, que tendem a não se encontrar, seja pela extrema fluidez em que ambos são jogados, levando-os a se esvaziar; seja pela tentativa de prevalência de um sobre o outro. Já nas experimentações de contato improvisação, que partem deste mesmo corpo cotidiano, mas que o expõem a outra forma do mover-se, talvez mesmo bastante simples e basilar: o contato do corpo com o chão. Isto é, a problemática que envolve a relação entre movimento e pensamento é trabalhada a partir deste contato corpo-chão e a sensação da gravidade. A partir daí se experimenta o movimento, que pode ser lento ou rápido, mas cuja qualidade é marcada pela densidade própria a este contato (corpo-chão) que não faz outra coisa senão devolver o movimento corporal à sua materialidade: o real redescoberto através do movimento. 
Nesse processo de reencontro com a matéria, o pensamento muda de qualidade também, indo em direção a ela (materializando-se), aproximando-nos do que Bergson chama de inteligência, ou seja, uma descida gradativa do espírito na direção da matéria, visando espacializar-se (Bergson, 1974, p. 126-7). Essa espacialização pode ser viabilizada pelo adensamento, na medida em que ele possibilita uma permeabilidade entre tempo e espaço, devolvendo-nos a um modo de experiência que se assemelha à ideia de duração bergsoniana: a reconciliação entre a continuidade (própria ao tempo) e a heterogeneidade (própria ao espaço) (Deleuze, 1999, p. 27).

Em outros termos, pode-se dizer que para além do movimento e do pensamento, há uma linha transversal que singra o corpo, a linha do acontecimento: "O acontecimento não é o que acontece (acidente), ele é no que acontece o puro expresso que nos dá sinal e nos espera" (Deleuze, 2003, p. 152). É um incorporal que atravessa o que se constituía como corpo. Não que este deixe de existir como superfície de inscrição e de expressão, mas não será como visibilidade plena, como estado de coisa. Pois o que se inscreve aí é a inevitabilidade do processo, e o que se expressa é a encarnação da força. Quando um acontecimento toca o corpo, expõe-no na sua processualidade: é um corpo em devir. É um corporar.

Corporar é o processo que arrasta pensamento e corpo a uma relação em que ambos se abrem às forças, ao intensivo, a partir de seus encontros e através de seus agenciamentos. Essa relação envolve um extra-ordinário corporal - e talvez o corpo não sustente mais seu nome, não consiga perpetuar nenhuma continuidade simples, torne-se denso. O adensamento é o método (a operação) para se corporar. A densidade que resulta desse processo é justamente a do encontro entre pensamento e corpo: um devir corpo só se torna possível quando as formas do agir e do pensar compactuam, e isso se produz através de uma densidade experimentada no movimento. Mas não pensemos que é o corpo que é adensado; é o movimento que o é. Ao corpo cabe experimentar os registros das passagens - seja por aceleração ou lentificação - viabilizadas pelo adensamento no ato de mover-se. O corpo é o índice de que algo se move. Ele é também a garantia de que não se tratam de puras ideias, ou de algum espírito impalpável. Ele é a materialização do movimento.

Deste modo, afastamo-nos da já citada utopia cibernética de um corpo-informação, criticada por Le Breton. No entanto, ainda permanece o risco de uma aceleração esvaziada, sem densidade, muito presente nalgumas práticas corporais contemporâneas, como é o caso exemplar das academias de ginástica e suas múltiplas modalidades de exercício, em que acelerar é a ordem do dia, pois a transformação do corpo passa por sua ligeireza.

Isso se dá por sermos tentados a pensar que as rupturas com o habitual se fazem pela aceleração, o que, num certo sentido, não deixa de ser verdadeiro. Mas precisamos considerar o que se objetiva com as acelerações, principalmente a tentativa de uma utópica supressão tempo-espaço no seio do que se tem chamado de "virtual". E precisamos considerar esses efeitos nas corporeidades. A primeira conse- 
quência, como uma forma de hipótese ao que tem acontecido ao corpo, na velocidade em que este tem sido jogado, é a banalização de um corpo-mercadoria, infinitamente transformável - o que, inclusive, tornou-se bastante desejável: mutabilidade, "fluidez", numa matéria plástica chamada corpo, aparentemente sem limites.

No entanto, este modo que muitos corpos encarnam traz consigo um complicador, pois se cai numa circularidade assaz infrutífera, em que a pressa tem feito da velocidade um fim em si mesma, e não mais um modo. Nesse processo, a intensidade foge do corpo, pois ela habita a própria velocidade, não 0 corpo. Semelhante ao que colocam Deleuze e Guattari a respeito de alguns riscos da (não) produção do corpo-sem-órgãos (CsO): "Havia mesmo várias maneiras de perder seu $\mathrm{CsO}$, seja por não se chegar a produzi-lo, seja produzindo-o mais ou menos, mas nada se produzindo sobre ele e as intensidades não passando ou se bloqueando" (Deleuze; Guattari, 1996, p. 23 - o grifo é meu).

Como uma forma de estratégia geral a nossa contemporaneidade, temos nos intensificado (ao menos o temos tentado) no próprio afã infinito de velocidade. Aos nossos corpos se grudam todos os clichês, sem seletividade, pois o que interessa é a aceleração, em que o movimento vale por si, e os corpos gozam de uma possibilidade metamórfica, ou melhor, de uma promessa de eterno futuro.

Poderíamos pensar que estamos no Eldorado da processualidade: nossa contemporaneidade como um manancial de transformação, de devir. Mas não é este, dos usos do dispositivo-corpo ${ }^{8}$, o que mais se efetiva ${ }^{9}$. Antes o contrário: a aceleração como forma de negar o devir - 0 devir do corpo, da vida, da morte.

O que se observa é uma aproximação à mudança, à modificação (algo como um "melhorar-se") na mesma proporção em que se procura negar o devir, uma vez que este envolve uma aproximação ao caos, ao informe, e nos coloca a dimensão do acontecimento. Isto é, nosso afã por velocidade é na verdade uma necessidade de aceleração: acelera-se a vida, principalmente o corpo, num mover-se frenético, justamente para espantar os devires ${ }^{10}$, pois não se suporta o acontecimento. De forma semelhante, lida-se mal com a desterritorialização, pois quando nos arriscamos nos limiares, não é como forma de aproximação ao Fora e à porosidade que então se faz necessária; mas como um melhoramento, rumo às imagens de perfeição \& sucesso que nos invadem. Daí que se tenha ojeriza do caos, principalmente em relação ao corpo. Por isso, também, que o frenesi do movimento (a aceleração) é uma forma de defesa, que nos resguarda da triste constatação da impermanência dos nossos corpos. E o que se quer são as mudanças, não as impermanências, pois estas inviabilizam qualquer tipo de voluntarismo: ao Eu-me-transformo voluntarista

8 A discussão sobre o corpo como dispositivo está alhures. Cf. Silva, 2007; Silva, 2006.

9 É um grande desafio lidar, atualmente, com aceleração e devir, sem se cair nos clichês do movimento, sobretudo no que diz respeito às artes cênicas e à dança: como promover velocidade, com leveza, e sem o frenético debater-se dos corpos, perdidos na sua própria falta de densidade?

10 Referência (invertida) a Deleuze que, a respeito das viagens (como professor, por exemplo), assim coloca: “... sou pouco inclinado a viagens; é preciso não se mexer demais para não espantar os devires." (Deleuze, 1992, p. 172). 
contrapõe-se o devir, em que algo acontece.

O acontecimento é justamente o que nos coloca frente ao esplendor das impermanências, jogando-nos num lancinante paradoxo, pois se deseja o acontecimento-esplendor, mas quase nunca aquilo que nos escapa. E é próprio ao acontecimento essa "dupla estrutura" 11: um presente de efetuação; e um passado-futuro, impessoal e pré-individual.

O que seria este impessoal, isso que nos escapa, este infinitivo que nos age, que atravessa o corpo? Talvez uma rajada de tempo, mas principalmente o silêncio. O silêncio do corpo, seu ócio, seu peso, seu vagar. Não se suporta um corpo que não se evidencia, que não comunica, que não se fala: tagarelice do corpo.

Os indícios das mutações que acometem o corpo são frequentemente recebidos com algum movimento antecipatório: alguma estratégia preventiva e uma piscadela de "eu-já-sabia". Por isso, e como não conseguimos lidar com essas mutações que nos assaltam, temos preferido habitar a circularidade da velocidade, como uma espécie de antecipação obsessiva: acelerar-se, modificar-se, apressar-se para não ser pego de surpresa pelo devir (novamente: do corpo, da vida, da morte...). É uma circularidade identitária: girar em torno de si mesmo, em que o Eu-me-transformo move-se infinitamente em torno do próprio umbigo.

Daí que adensar surja como a possibilidade de uma experimentação do corporar. $O$ adensar como um modo do corporar, como um silêncio falado, uma pausa atuada, agida. Mas adensar é um trabalho paciente: "Não se atinge o CsO e seu plano de consistência desestratificando grosseiramente" (Deleuze; Guattari, 1996, p. 23). Adensar envolve prudência em toda experimentação.

No entanto, quando surge a temática da prudência, logo vem atrelada à da conservação. Pois temos essa necessidade de reposição, de recolocar o corpo em seu lugar, de reconstruí-lo como morada humana a cada vez, de novo e sempre "humano, demasiado humano", como nos alerta Nietzsche ${ }^{12}$. Porque, afinal, a negação do devir no/do corpo requer uma paciente e infinita operação de adequação, que mescla ajuste e mudança. E que, de um modo geral, refere-se à conservação, não propriamente do corpo, pois este deve ser transformável; mas de um modo de existência que se perpetua através das infinitas transformações. Como se a experimentação servisse à conservação, quando o que se busca, no intuito de potencializar a vida, é o contrário: um mínimo de conservação que sirva à experimentação.

Por isso, é preciso não se falar em conservação, que traz atrelada a si a ideia mesma da permanência. Retomando o que já dissemos acima, falemos de prudência e em como isso se daria em termos de

11 Para o que se segue sobre acontecimento, cf. Deleuze, 2003 p.151 e ss.

12 Referência ao livro de Nietzsche, de mesmo título, em que o autor critica toda uma série de "sentimentos morais" que têm reduzido a vida a seus níveis mais baixos de potência, na figura do "homem moral", que reflete a necessidade metafísica do (tipo) homem. Contra isso, Nietzsche inventa os "espíritos livres", como uma forma de antídoto. Cf. Nietzsche, 2000. 
experimentação. Ou seja, como pensar experimentalmente a sutil diferença - ou mesmo possíveis aproximações - entre prudência e conservação?

Como exemplo, é possível citar uma experimentação da dança. Um dançarino realiza um determinado rolamento: deitado com as costas no chão, joga as pernas na direção da cabeça, para rolar para trás e subir numa grande bola. De repente, um descuido: rola de forma errada, deixando a cabeça e pescoço retos, causando um estiramento da coluna, machucando-se. Na hora não para, e continua a dançar. No dia seguinte, não consegue mexer o pescoço. E, dias depois, mesmo recuperando a mobilidade do pescoço, a dor e uma certa resistência a movimentos na região persistem, e assim por várias semanas. Ou seja, o resultado é uma redução das possibilidades de movimento, logo, de experimentação. Este exemplo pode nos indicar um caminho, qual seja, pensar a prudência como forma de garantir a continuidade e, no melhor dos casos, a ampliação das experimentações.

Mas haveria diferença entre prudência e conservação? Seria útil diferenciá-las? Se referidas às experimentações, podemos distingui-las da seguinte forma: a conservação nos remete mais à permanência de um estado de coisas (questão essencialista); enquanto que a prudência nos remete a modos, a um como: como fazer tal coisa (questão de funcionamento). Em termos "espinosistas"13, teríamos uma conservação-moral e uma prudência-ética.

É claro que, colocado dessa forma, a prudência - diferentemente da conservação - não nos assenta na plena segurança. Mas nem tampouco a conservação garante a plena segurança-em-vida; apenas seu ideal é uma aposta de que a evitação dos limiares, de que a permanência nas raias do normal venham a promover o paraíso na Terra. E isso parece responder a uma demanda de "maioria", de rebanho, de todas essas pessoas comuns, que somos todos de alguma forma, e que tentamos a muito custo alinhavar nosso corpo em desagregação: uma espécie de plástica como prática de alisamento do Frankenstein que nunca deixaremos de ser. $O$ ideal da conservação é Dorian Gray, de Oscar Wilde: ah! se pudéssemos confinar todas as marcas das processualidades, dos fluxos que nos atravessam num quadro escondido no sótão...

As experimentações deixam marcas. A diferença se encontra na sutileza dessas marcas, como condição para a experimentação e sua continuidade. Como coloca Lapoujade - inspirado em Nietzsche:

\begin{abstract}
(...) as feridas são as mais sutis. Isto quer dizer que a exposição do corpo se faz no interior dos mecanismos de defesa ... e que o protegem das feridas mais grosseiras. Sutil, aqui, não quer dizer leve ou benigno, mas, ao contrário, quer dizer que as defesas operam suficientemente para que eu tenha acesso à profundeza e à violência de uma ferida sutil - ou, inversamente, que eu tenha acesso à sutileza que esconde uma ferida grosseira. (Lapoujade, 2002, p. 88)
\end{abstract}

13 Refiro-me à distinção que Espinosa faz entre ética e moral (cf. Deleuze, 2002, pp. 28 e ss.; Espinosa, 1991). 
Voltando ao exemplo narrado acima, a prudência do dançarino o conduziu (mais ou menos intacto) até o mal-realizado rolamento. No entanto, ela não é a suprema guardiã, pois é preciso explorar o movimento, e isso envolve risco. Não nos cabe, pois, repreender a experimentação, ou o nosso ato de experimentar, como se ele fosse a causa de nosso infortúnio. Pois o que está em questão é o modo, e não a própria realização do movimento. Só que a esse como, que nos intriga, não encontraremos resposta definitiva que nos salvaguarde da dor e até mesmo da morte. Pois a prudência apresenta-se como esse mínimo de conservação que não nega o trágico, mas que busca trair-lhe o desfecho final: primeiramente, a morte física, mas também a morte-em-vida.

Dito de outra forma, a prudência é uma tentativa de afirmação, através da experimentação, da vida contra a dor e a morte, mas que não as nega. $E$ isso nos assusta, e por isso ficamos mais frequentemente na conservação. Mesmo porque nossos corpos são machucados, doem e se atemorizam frente às experimentações. Afinal, não devemos esquecer que nossa história recente marcou nossos corpos de uma maneira muito específica e dolorosa, através de uma ditadura militar (entre os anos 1960-1980)14, que agiu e age no invisível do corpo vibrátil, calando a potência de criação, e associando-a ao medo de morrer ${ }^{15}$. E o que se busca, então, é acabar com a angústia que as forças do mundo provocam nesse corpo que não se cala, mas que não consegue, muitas vezes, articular sua fala: corpo gago. E se, por um lado, as identidades podem inspirar alguma segurança, pois organizam, garantem e conservam; por outro, algo aí se estanca, e muitos fluxos vitais são barrados.

Como se situaria o corpo nesse contexto? Podemos traçar o seguinte diagrama: linhas de experimentação, linhas de prudência, linhas de conservação, e linhas mortiferas nos atravessam; e o corpo é 0 ponto em que estas linhas se entrecruzam. A partir disso, podemos entender como se busca afastar 0 risco, e o que sobra, então, é o corpo sem o que por ele passa, sem o que o atravessa.

Se, para Deleuze e Guattari, o corpo-sem-órgãos ( $\mathrm{CsO}$ ) é um meio pelo qual os fluxos podem se escoar, em que as intensidades circulam, é o indeterminado, em relação à determinação dos órgãos (sua organização); o que temos em nossa contemporaneidade assemelha-se mais ao contrário: um corpo-comórgãos. A conservação da vida tornou-se um dever e um estandarte, que deve ser empunhado e exibido. Paradoxalmente, o corpo humano pode não ter mais uma essência, sem com isso deixar de ser essencialmente humano, em seu modo de constituição e de manutenção, isto é, em sua conservação.

Esse corpo, reconstruído como morada humana a todo o momento, leva-nos a crer que o que se tem buscado é justamente conservar o humano através do corpo. Mas o que seria isso? É a operação humana - demasiadamente... - de se refletir nas coisas, de se enfiar nelas e crer que é próprio das coisas

14 Mas não só. Se a ditadura militar é nossa herança, cuja dor se inscreve em grande medida em nossas corporeidades, há também todo um rol de violências e agressões cotidianas, das mais "simbólicas", às mais "concretas" e encarnadas. Para a discussão sobre as marcas nos corpos operadas pela ditadura militar brasileira de 1964-1985, Cf. Silva, 2006 , p. 35 e ss.

15 Reflexão desenvolvida por Suely Rolnik, no seminário Produção de Sentido, Produção de Si I, do Programa de PósGraduação em Psicologia Clínica - Núcleo de Subjetividade, PUC-SP, 09/11/2005 (anotação de aula). 
serem assim - humanas. Além disso, há o voluntarismo: um sujeito que age e de onde emanam as ações. E, por fim, a negação do trágico. Não teria o corpo passado por essa re-humanização? Não estaria ele passando por isso, tornando-se a imagem-e-semelhança do sujeito, que outrora o comandava, como coisa estranha, alheia, do alto de sua razão redentora, e que agora parece ver-se espelhado em seu corpo?

Mais de quatro séculos nos separam de Espinosa (1991), e, na verdade, há algo de inquietante desde lá. Mas a pergunta espinosista volta transmutada: o que pode um corpo - o que pede um corpo... quem pede um corpo? O quem não é uma simples ironia de ocasião, jogo de palavras. O quem responde por uma identificação: eu sou meu corpo. É uma tentativa de apropriação de si através do corpo identificado, com seus índices de adequação (o prazer, a saúde etc.). O corpo é chamado a prestar contas de si, é chamado a falar-se, a apresentar-se, e a representar-nos.

Todos os possessivos que costumamos usar (meu corpo, meu sexo, minha vida etc.) não marcam supostos territórios que colonizamos e que nos pertencem, pois o corpo-imagem só existe no ato de sua exteriorização visível. O meu corpo é primeiramente a marca de uma (eterna) busca, mas também é 0 indicativo de adequação, em que "corpo" é o modo de exibição; e "meu" é o que me identifica a ele, me subjetiva nele.

Daí que o que pedimos é o nosso corpo. Por isso que falar em corpo-sem-órgãos seja, amiúde, impensável, pois corpos e órgãos viraram outra coisa. Eles foram reorganizados e, em vez de engendrarem uma indeterminação aberta, eles se prestam a encarnarem uma organização que se apresenta como a imagem hi-tech do humano. É o índice de nossa impossibilidade de arrancar as corporeidades do território humano que as restringe. A imagem que podemos utilizar para exemplificar isso é a dos filmes de ficção científica, em que as forças e formas alienígenas acabam sempre se rebatendo sobre o humano numa espécie de antropomorfismo inexorável: o cinema de ficção científica como diagnóstico de nossa incapacidade de lidar com um além-corpo, que não seja desencarnado (pura energia, ou informação ou qualquer outro blá-blá-blá do gênero).

Corpo-sem-órgãos parece estranho, atualmente, quando vivemos um momento em que nos aproximamos mais de órgãos-sem-corpo ${ }^{16}$. Ou ainda, de um modo de subjetivação que não se fixa em órgãos ou ao próprio corpo, embora passe necessariamente por eles. Corpos e órgãos tornaram-se fluídos, embora em sua insustentável e esvaziada fluidez, demarquem um mais novo espaço de interdições. A impressão que fica, passado o frêmito das excitações momentâneas, é que o corpo foi esvaziado. Não esvaziado de coisas, mas de potência disruptiva. E resta a questão: seria possível pensar um além-corpo a partir da carne?

A carne não é o que de mais próprio existiria no corpo; ela é fome de mundos, o que desfigura,

16 Vem à mente uma imagem do filme Clube da Luta (Fight Club, EUA, 1999, Dir.: David Fincher), em que, numa determinada cena, o personagem principal lê trechos de uma revista em que os órgãos de alguns pacientes falam em primeira pessoa: "Eu sou a medula de Fulano-de-tal... etc.". 
para voltarmos a Deleuze-Bacon. Ela não nos preenche, não é nosso estofo. A carne é um movimento que singra o corpo. Trata-se de um atletismo da carne, à maneira que Artaud fala de um "atletismo afetivo", isto é, "uma saída corporal para a alma" (Artaud, 1993, p. 131).

A pulsação da carne atravessa as estratificações que até aqui examinamos: o corpo acuado, amedrontado e dolorido; o investimento de um determinado discurso neurocientífico que, juntamente com as novas tecnologias informáticas (e a euforia pós-corpórea de seus entusiastas), ajudam a compor o corpo-informação; e a impalpabilidade do corpo-imagem. Dor e mudez, evidência plácida e a falta de densidade, estes efeitos das estratificações mais frequentes que fazem corpo e que se podem visualizar na atualidade, são problematizadas pela carne.

Porque, afinal, não se deixa de falar, mesmo que estranhamente, ou de modo bizarro e muitas vezes grotesco; também não se deixa de conquistar consistência nalgumas experiências subjetivocorpóreas. Uma força vital não deixa de pulsar nos corpos, desfigurando-os, contorcendo-os.

E se há um corpo emudecido que gagueja ao tentar se expressar, há também um movimento que inventa uma nova língua em ato: corporar.

\section{EXPRESSAR}

Numa sociedade da informação, como a nossa, como poderia o corpo escapar desse regime? Aliás, contemporaneamente, o que nos permite agrupar certas práticas sob o nome de corpo assenta-se, de algum modo, num regime de produção de informações sobre o corpo.

A esta visibilidade - o corpo-informação -, como estrato contemporâneo, vem-se juntar um corpoimagem como modo de subjetivação o mais cotidiano. 0 corpo é uma imagem, e os processos de adequação se direcionam mais ou menos à produção de si através do corpo, em conformidade com imagenspadrão veiculadas e difundidas. Mas não aleatoriamente, pois há boas e más imagens: uma nova moral, que delimita uma outra divisão entre o Bem e o Mal se insinua aí.

O que importa é que o corpo se torne imagem, pois se há alguma potência nele ativada é justamente a de exibição. Nesse procedimento, o movimento aparece, na maioria das vezes, não como uma potência vital, mas como elemento de trânsito entre imagens, como um elo de ligação que une um antes e um depois: ele é a linha (às vezes o caminho mais curto) entre dois pontos. 0 movimento, aqui, é usado como ponte que leva de uma imagem à outra. 
O efeito que se tem é o de um corpo dócil, ou melhor, re-docilizado, capturado pela onipresença da sua imagética, em que as subjetividades são corporalizadas segundo o mesmo registro, através de imagens-padrão: corpo-sucesso, corpo-saudável, corpo-atraente etc. E não se escapa disso por intermédio de outras imagens (território facilmente capturável), como se o simples reverso das imagens-padrão nos conduzisse a fugas de seu registro. É através de uma outra qualidade de movimento, que consiga colocar em jogo outras potências do corpo, que o tire de seu particularismo e de sua pertença a este território das puras imagens que encontraremos linhas de fuga que estejam à altura dos fluxos vitais que pedem passagem.

Se não quisermos reduzir o corpo a uma entidade - "O" corpo - que nos identifica e dessa forma guia nossa subjetivação, é preciso sublinhar a multiplicidade para além de qualquer pluralidade fácil. É preciso tirá-lo de sua evidência e transparência, que o identifica. Pois, ao mantermos estes anseios transparência e evidência - não fazemos mais que reacomodar imagens em nosso corpo-tela; ou softwares, em nosso corpo-hardware. Ou seja, mais e mais evidências.

Se há ainda alguma potência disruptiva no que se tem experimentado como corpo (que efetivamente são corporeidades), esta advém do mistério, da surpresa, logo de uma forma de relação com 0 Fora, isto é, com o campo de forças. Se quisermos ativar esta potência temos que correr o risco de desfigurar o corpo: levá-lo a seus limiares, expô-lo às forças, ao intensivo, mesmo porque talvez seja essa sua - do corpo - insuportável vocação. Neste aspecto, expressar assume outro sentido: para além de alguma imagem confortável, tornar visível no corpo o registro das processualidades que o riscam, que o marcam. A expressão do intensivo.

Pois expressar não é exibir, não é fazer transparecer, não se refere a alguma forma de simplesmente tornar conhecido o desconhecido. Não se refere, enfim, ao cognoscível, a uma modalidade da informação. Pelo contrário, é aprofundar o mistério, é torná-lo mais irredutível. Se há alguma razão para se falar em expressão, é no sentido em que o que se expressa não são imagens, mas forças. Uma pulsação vital que pede passagem e que pede forma, e na sua procura por forma, a força deforma o que estava formatado (o corpo), e abre passagem para o informe (a carne). A corporeidade que se abre às passagens não se sustenta mais como corpo (identificado), pois é deformativa. E o movimento pode ser uma solução para se evitar o colapso, que ameaça as experimentações, quando não há forma para abrigar a força, e ela, ou se detém, ou - dependendo da intensidade - desfigura grosseiramente, à maneira da ferida grosseira de que nos falava Lapoujade.

Pensemos, então, numa deformação sutil, numa espécie de limiar, numa forma que agregue movimento e imagem deformada, que parta dos contornos, alargando-os e deformando-os. Pensemos na sombra, como uma forma mínima de exteriorização, que se sustenta no limite do informe: as sombras do corpo. Não como o obscuro, ou o falso. Mas a sombra como um delineamento das forças escapando ao corpo (virtual), do qual ele, em sua organização, se afasta. Aí temos a sombra, riscando um outro corpo 
num lugar qualquer (no chão, por exemplo). E ela, que depende de uma fonte de luz e de um anteparo, forma uma composição: algo se produz na composição luz-corpo-anteparo, no entre. A sombra do corpo é dependente do modo como a luz incide, logo é um corpo perspectivado. Também depende do anteparo, que pode ser plano ou irregular, por exemplo, produzindo sombras diferentes. Portanto, a sombra produz um outro contorno a partir do corpo, ou melhor, um movimento corporal que não é mais corpo, mas um corporar.

Não há feições na sombra. Há um traçado, uma geografia, ou melhor, uma cartografia do movimento. É ruptura e esboroamento das formas bem traçadas, organizadas, em proveito da produção de linhas instáveis, da ampliação de algumas potências do corpo: por exemplo, de lentificação, desaceleração na dança das sombras.

De todo modo, e por estranho que pareça, há, através da sombra, um devir-corpo. Há um corposem-órgãos que é possível vislumbrar nos tênues e instáveis contornos borrados das sombras, que permitem não negar o corpo, mas cruzar-lhe as fronteiras. Como se o mais superficial (a pele) fosse duplicado e ganhasse outros contornos nessa exteriorização instável, remetendo-nos a profundidades até então inaudíveis e inexpressáveis. $E$ eis que a máxima de Paul Valéry ganha sentido: o mais profundo é a pele.

No entanto, não há densidade na sombra; é um corpo chapado num anteparo qualquer. É por isso que, se por um lado a sombra é uma linha de fuga para o corpo, uma dobra que libera os fluxos na carne; por outro, ela não é uma solução, uma garantia, nem uma fórmula, ou um ponto de chegada. Ela é uma pista para pensarmos uma exteriorização instável e informe, que sublinha a prevalência do movimento. $A$ sombra nos recoloca no mistério, como forma de expressão; mas é o movimento que nos abre ao adensamento e ao corporar.

\section{MOVIMENTO}

Falamos acima de um corpo-imagem cujo movimento traça o percurso de uma imagem a outra, e que nos enreda num procedimento expressivo em que não se sai da circularidade das imagens. Por outro lado, temos a sombra como um mínimo de expressão, em que a imagem se desfigura, perde seus contornos, e sublinha a prevalência do movimento. Mas a sombra é desencarnada. Ela é somente 0 indício de que um corpo-carne é possível. Mas como pensá-lo? Ou melhor, como pensar a desfiguração no próprio corpo, não como falência, mas como ampliação, como um mais além, um passo à frente? Em que o movimento se diferenciaria da expressão? Ou ainda: qual relação há entre movimento e expressão?

O movimento, antes de ser o que move o corpo, é algo que se move no corpo. Nesse procedimento, o corpo é a forma que se presta e se empresta ao movimento, sendo que este, uma vez tomado pelo 
movimento, faz-se corpo em ação. É um processo, em que o intensivo percorre o corpo, evidenciando neste as passagens dos fluxos. É corporar, que em muito se diferencia das formas de identificação (sercorpo).

Mas o movimento aqui referido não é qualquer um, e sim um movimento de agenciar: compor, conectar. E se pode-se falar em corpo - como em corpo intensivo - é no sentido de uma composição. Essa composição deve funcionar como dispositivo, de modo a pôr em relação interior e exterior, superfície e profundidade. Compõe-se no, pelo e para o movimento, e daí pode-se dizer que se expressa. Não como um corpo expressivo, cuja inelutável vocação seria a de se evidenciar, e que objetivaria se desvelar, revelar-se ou algo parecido; mas como corpo intensivo que se faz forma, que encontra uma forma. 0 que se expressa, pois, é o movimento das forças, das intensidades encarnadas no corpo, ou seja, os mapas traçados pelo intensivo.

Nesse aspecto, podemos pensar em distintos níveis ou registros corporais, que se referem a diferentes modalidades expressivas. Tomemos como base uma distinção utilizada pelo teatro Nô japonês ${ }^{17}$. Segundo os ensinamentos de Zeami (final do século XIV) o ator de Nô é composto por três condições fundamentais: pele, carne e esqueleto (Amagasaki, 1996, p. 27). A pele é sua superfície mais evidente, sua bela aparência; a carne é o movimento, conquistado através dos exercícios; e o esqueleto é seu corpo em estado latente, intenso, virtual (Amagasaki, 1996, p. 28). O objetivo é atingir a este último, pois é dele que emana a dança.

Essa distinção em muito nos serve, pois o movimento que se pretende aqui ressaltar é justamente aquele que nos permita atingir as intensidades desse esqueleto. Afinal, a pele, essa superfície aparente e evidente, já há muito que tem sido capturada pela indústria da imagem e pelo sistema de produção e consumo. Mas também a própria carne, talvez em menor medida, é convocada a se identificar, a se amoldar a uma forma de movimento padrão, seja ele o da agilidade, da competitividade (incluída aqui a resistência), da "fluidez", da espontaneidade etc. E nosso esqueleto, essa porção intensiva e virtual é o que parece ser mais indócil, o mais avesso às capturas.

Na verdade, é preciso pensar na tensão própria a estes diferentes níveis da experiência corporal, e que se tornam visíveis na dança. Talvez possamos pensar aqui na small dance de Steve Paxton, como discutida por Gil (a partir das descrições do próprio Paxton): "É o movimento microscópico que descobrimos no interior do nosso corpo e que o mantém de pé" (Gil, 2004, p. 109). Esse "movimento microscópico", essa tensão que nos passa despercebida na maioria das vezes, isto tudo pode ser remetido à ideia de esqueleto, como descrita acima.

Mesmo porque, em muitos exercícios de dança contemporânea focaliza-se muito a coluna vertebral, bem como os próprios ossos: a coluna com seus movimentos ondulatórios, serpenteantes; os ossos

17 Para o que segue sobre o teatro Nô, cf. Amagasaki, 1996. 
em suas relações de aproximação e afastamento entre si. Há dois exemplos neste sentido: a coluna é evocada para se experimentar o movimento reptiliano, é ela que deve conduzi-lo, a partir de sua potência ondulatória; e os ossos são presentificados, por exemplo, num exercício em que se experimentam linhas imaginárias ligando diversos ossos do corpo (occipital-cóccix, ísquios-calcanhares etc.), seus afastamentos e aproximações.

Esqueleto-carne-pele são postos em relação, no movimento dançado, para que a vida pulse, ou, para sermos deleuzianos, atualize-se. Pois, se há um corpo virtual que se atualiza no movimento dançado, como coloca Gil (2004, p. 24), é porque esta qualidade de movimento permite a construção do corpo-semórgãos, na medida em que "esvazia o corpo dos seus órgãos desestruturando o organismo", instaurando nele uma nova relação com o vazio, que não é de falta, mas de uma plenitude de potências, ou melhor, um vazio-pleno18. Ou ainda, na belíssima formulação de Quilici, referindo-se a Artaud: "Corpo sem órgãos, corpo multidão, corpo que acolhe o vazio" (Quilici, 2004, p. 203).

Mais que um corpo, que o corpo, trata-se aí de corporeidades, ou melhor, de formas de corporar. E o vazio, para além da falta, funciona como uma limpeza de terreno, uma espécie de deserto que é fruto da ação de desertar, fugir, fazer fugir. E que é preciso povoar, com novas matilhas, com novas legiões nômades e indomáveis. Pois se trata aqui não mais de um corpo dado, que é preciso carregar; mas de um processo em que as corporeidades são colocadas em devir.

O corpo, no movimento dançado, atualiza a carne, em sua dor e em sua alegria e festa. Abre espaço, inclusive para uma relação corpo-pensamento através do movimento, em que o sentido inventa palavras, empurrando-as garganta afora. A voz, então, é um ato desse corpo em movimento, que forma fluxos de interiorização e exteriorização. É aí que se vislumbra a composição de um espaço público para o corpo, que não seu mero espetáculo ou sua imagética espetacular. É a afirmação do corpo, da voz e da vida pública. Mas é também a reinvenção da imagem do corpo, através da potencialização do movimento.

Enfim, a dança abre em leque o corpo, tornando-se um campo de possibilidades para o exercício do corporar. Confere uma possibilidade de se criar uma voz possível através do movimento. Para além do espetáculo e da imagética contemporâneos, mas sem negar sua época (seu presente), o movimento do corpo-em-dança é uma modalidade para se experimentar a vida em sua potência de invenção e resistência.

\section{REFERÊNCIAS}

18 A noção de "vazio pleno" é de Lygia Clark. Nas palavras de Rolnik, refere-se à "experiência do corpo vibrátil nos momentos em que se processa o esgotamento de uma cartografia, quando está se operando a silenciosa incubação de uma nova realidade sensível, manifestação da plenitude da vida em sua potência de diferenciação." (Rolnik, 2001, p. 319). 
AMAGASAKI, Akira. O corpo reinventado. Correio da UNESCO, ano 24, n.3, Rio de Janeiro, março/1996. pp.27-30.

ARTAUD, Antonin. O Teatro e seu Duplo. Tradução Teixeira Coelho. São Paulo: Martins Fontes, 1993 [1964].

BERGSON, H. O Pensamento e o Movente. São Paulo: Abril Cultural, 1974 [1919]. (Os Pensadores).

DELEUZE, Gilles. Lógica do Sentido. 4. ed. Tradução Luiz R.S.Fortes. São Paulo: Perspectiva, 2003 [1969]. (Estudos, 35).

Espinosa: filosofia prática. Tradução Daniel Lins e Fabien P. Lins. São Paulo: Escuta, 2002.

Bergsonismo. Tradução Luiz B. L. Orlandi. São Paulo: Ed. 34, 1999 [1966]. (TRANS).

Conversações. Tradução Peter Pál Pelbart. São Paulo: Ed.34, 1992 [1990]. (TRANS).

Francis Bacon: logique de la sensation. Paris: Éditions de la Difféfence, 1981.

DELEUZE, Gilles; GUATTARI, Felix. Mil Platôs: capitalismo e esquizofrenia. Vol. 3. Tradução Aurélio Guerra Neto et. al. São Paulo: Ed. 34, 1996 [1980]. (TRANS).

ESPINOSA, Baruch de. Pensamentos Metafísicos; Tratado da Correção do Intelecto; Ética. 5. ed. São Paulo: Nova Cultural, 1991 [1677]. (Os Pensadores)

GIL, José. Movimento Total. São Paulo: lluminuras, 2004.

O corpo paradoxal. In.: LINS, Daniel; GADELHA, Sylvio. (Org.). Nietzsche e Deleuze: que pode o corpo. Rio de Janeiro; Fortaleza: Relume Dumará; Secretaria da Cultura e Desporto, 2002.

LAPOUJADE, David. O corpo que não agüenta mais. In.: LINS, Daniel; GADELHA, Sylvio. (Org.). Nietzsche e Deleuze: que pode o corpo. Rio de Janeiro; Fortaleza: Relume Dumará; Secretaria da Cultura e Desporto, 2002.

LE BRETON, David. Adeus ao corpo. In.: NOVAES, Adauto. (Org.). 0 Homem-Máquina: a ciência manipula o corpo. São Paulo: Companhia das Letras, 2003. Pp. 123-137.

LEVY, Tânia Salem. A Experiência do Fora: Blanchot, Foucault e Deleuze. Rio de Janeiro: Relume Dumará, 2003. (Conexões, 19).

LINS, Daniel; GADELHA, Sylvio. (Org.). Nietzsche e Deleuze: que pode o corpo. Rio de Janeiro; Fortaleza: Relume Dumará; Secretaria da Cultura e Desporto, 2002.

NIETZSCHE, Friedrich W. Humano, Demasiado Humano: um livro para espíritos livres. Tradução, notas e posfácio Paulo César de Souza. São Paulo: Cia. das Letras, 2000 [1878, 1886].

Genealogia da Moral: uma polêmica. Tradução, notas e posfácio Paulo César de Souza.

São Paulo: Cia. das Letras, 1998 [1887]

NOVAES, Adauto. (Org.). 0 Homem-Máquina: a ciência manipula o corpo. São Paulo: Companhia das Letras, 2003.

QUILICI, Cassiano Sydow. Antonin Artaud: teatro e ritual. São Paulo: AnnaBlume; FAPESP, 2004.

ROLNIK, Suely. Cartografia Sentimental: transformações contemporâneas do desejo. Porto Alegre: Sulina; Ed. da UFRGS, 2006

"Fale com ele" ou como tratar o corpo vibrátil em coma. In: GALLI FONSECA, Tânia; ENGELMAN, Selda (Org.). Corpo, arte e clínica. Porto Alegre: UFRGS, 2004.

Molda-se uma alma contemporânea: o vazio-pleno de Lygia Clark. In.: BEZERRA Jr., 
Benilton; PLASTINO, Carlos Alberto (org.). Corpo, Afeto e Linguagem: a questão do sentido hoje. Rio de Janeiro: Contracapa, 2001.

SANT'ANNA, Denise B. de. Corpos de Passagem: ensaios sobre a subjetividade contemporânea. São Paulo: Estação Liberdade, 2001.

SILVA, Jardel Sander da. Movimento Corporal e Processos de Subjetivação: um olhar através da dança. In.: SOUZA, Olga M.M.C. de; SOUBBOTNIK, Michael A. (orgs.). 0 Corpo e suas Fic(xa)ções. Vitória: PPGL/MEL, 2007. pp.184-192.

Camelos também dançam. Movimento corporal e processos de subjetivação contemporâneos: um olhar através da dança. 2006. Tese (Doutorado) - Pontifícia Universidade Católica de São Paulo - Núcleo de Subjetividade, São Paulo. 